\title{
Immunogenicity of two different hepatitis B vaccine schedules
}

\author{
S. Y. Agladioglu • U. Beyazova $\cdot$ A. D. Camurdan • \\ F. Sahin • A. Atak
}

Received: 12 April 2011 / Accepted: 7 June 2011/Published online: 30 June 2011

(C) The Author(s) 2011. This article is published with open access at Springerlink.com

\section{Dear Sir,}

A letter by Rashmi Ranjan Das et al. was recently published in Infection in which the authors commented on our article entitled "Immunogenicity of recombinant hepatitis B vaccine: comparison of two different vaccination schedules" [1]. We would like to take the opportunity provided by this letter to discuss our findings in particular and hepatitis B epidemiology in Turkey in general.

The study performed by Das et al. [2] is one of the few published to date that compares different vaccination schedules of hepatitis B immunization in children [2-4]. These authors performed a randomized clinical trial on the immunogenicity of two different hepatitis B vaccine schedules, i.e., birth, 6 weeks, and 14 weeks (Group A) or 6,10 , and 14 weeks (Group B), and found that seroconversion rates for hepatitis $\mathrm{B}$ vaccine were comparable in the two groups. In contrast, two other studies [3, 4], similar to our study, revealed lesser seroconversion in infants whose vaccination started immediately after birth. Such data will contribute to the generation of recommendations

\footnotetext{
S. Y. Agladioglu

Department of Pediatrics, Medical Faculty,

Gazi University, Ankara, Turkey

U. Beyazova · A. D. Camurdan · F. Sahin

Department of Social Pediatrics, Department of Pediatrics, Medical Faculty, Gazi University, Ankara, Turkey

A. Atak

Department of Immunology, Medical Faculty,

Gazi University, Ankara, Turkey

A. D. Camurdan $(\bowtie)$

Eryaman Mahallesi, Emre sokak, 354. sok,

Yeşilöz sitesi No: 8/5, 06930 Etimesgut, Ankara, Turkey

e-mail: aysucamurdan@yahoo.com
}

on the optimal timing of the initial dose of hepatitis B immunization in infants. In addition to seroprotection, other factors, such as the feasibility of screening for hepatitis B virus surface antigen (HBsAg) in pregnancy and changing epidemiology of the disease in vaccinated populations will also have an effect on these recommendations.

With respect to hepatitis B epidemiology in Turkey, we agree with the conclusions of Das et al. [2]. It is likely that vaccinated children born to HBsAg-positive mothers or living in areas where hepatitis B infection is endemic are exposed to hepatitis B throughout childhood. Such children can obtain natural booster doses, which is also an approach to be considered in countries with moderate endemicity. Turkey is known to have moderate hepatitis B endemicity, but in the previous decade the prevalence of HBsAg positivity declined from 4.19 to 2.10 [5-8]. Although hepatitis $\mathrm{B}$ infection seroprevalances are accepted to have increased in the more eastern regions in Turkey relative to the western ones, a recent study found that the incidence of hepatitis B carriers in pregnancy was $2.1 \%$ in southeastern regions of Turkey [9]. This decrease is the result of the implementation of hepatitis B vaccination programs for infants in 1998 and catch-up vaccination programs for school-age children. According to Turkish Ministry of Health data, the hepatitis B coverage rate for infants $<1$ year of age in 2010 was $95 \%$, and incidences of HBsAg positivity for children $<5$ years of age were $3 / 100,000$ and $0.5 / 100,000$ in 2005 and 2010, respectively [10]. Turkey is shifting from moderate to low endemicity and, consequently, the possibility of repeated sub-clinical exposure and natural boosters is also decreasing. These facts support the comment made in our study "as children need longterm protectivity and if immunological memory may later decline or become undetectable, the risk of breakthrough infection may occur". 
Infants born to $\mathrm{HBsAg}$-positive mothers should receive the first dose of hepatitis $\mathrm{B}$ vaccine at birth, but the first dose may be given at a later age for other children. However, screening is costly and not usually feasible in Turkey. In countries where screening programs for pregnancy are not available, vaccination at birth for hepatitis B perinatal infections is still a necessity. We agree with Das et al. [2] on the necessity of post-vaccination follow-up of different schedules, including birth dose of vaccination with seroepidemiological studies. As we emphasized previously, our study is a preliminary report and we plan to follow up these infants until puberty and evaluate their immunological status.

\section{Conflict of interest None.}

Open Access This article is distributed under the terms of the Creative Commons Attribution Noncommercial License which permits any noncommercial use, distribution, and reproduction in any medium, provided the original author(s) and source are credited.

\section{References}

1. Agladioglu S, Beyazova U, Camurdan AD, Sahin F, Atak A. Immunogenicity of recombinant hepatitis $\mathrm{B}$ vaccine: comparison of two different vaccination schedules. Infection. 2010;38(4): 269-73.
2. Das RR, Mathew JL, Ratho RK, Dutta S. Randomized clinical trial comparing hepatitis $\mathrm{B}$ vaccine administered by 0,6 , and 14 week versus 6,10 , and 14 week schedule in healthy infants. J Trop Pediatr. 2009;55:328-31.

3. del Canho R, Grosheide PM, Voogd M, Huisman WM, Heijtink RA, Schalm SW. Immunogenicity of 20 micrograms of recombinant DNA hepatitis B vaccine in healthy neonates: a comparison of three different vaccination schemes. J Med Virol. 1993;41:30-4.

4. Bassily S, Kotkat A, Gray G, Hyams KC, Brown FM, Imam IZ, Arthur R. Comparative study of the immunogenicity and safety of two dosing schedules of hepatitis B vaccine in neonates. Am J Trop Med Hyg. 1995;53:419-22.

5. Gurol E, Saban C, Oral O, Cigdem A, Armagan A. Trends in hepatitis B and hepatitis $\mathrm{C}$ virus among blood donors over 16 years in Turkey. Eur J Epidemiol. 2006;21(4):299-305.

6. Polat S, Camurdan AD, Aksakal N, Agladioglu S, Beyazova U, Sahin F, Atak A, Er A. Evaluation of perinatal and intrafamilial hepatitis B prevention programmes in a well child clinic: 9-year follow-up study in Turkey. Trans R Soc Trop Med Hyg. 2011; 105(4):220-5.

7. Akcam FZ, Uskun E, Avsar K, Songur Y. Hepatitis B virus and hepatitis $\mathrm{C}$ virus seroprevalence in rural areas of the southwestern region of Turkey. Int J Infect Dis. 2009;13(2):274-84.

8. Altinbas S, Erdogan M, Danişman N. The seroprevalences of $\mathrm{HBs} \mathrm{Ag}$ and anti-HCV in pregnant women in Ankara. Arch Gynecol Obstet. 2010;281(2):371.

9. Araz NC, Dikensoy E. Seroprevalence of hepatitis B among pregnant women in southern Turkey. J Pak Med Assoc. 2011;61(2):176-7.

10. Turkish Ministry of Health Unpublished surveillance data. Turkish Ministry of Health, Istanbul; 2011. 